\title{
Artículo Especial: Obras maestras del arte universal en la problemática médica: "La muerte de Iván Ilich" (León Tolstoi, 1828-1910)
}

Carlos Musso*

\begin{abstract}
Argumento
Iván llich era un juez de instrucción en la Rusia zarista, quien pese a estar satisfecho con su condición de adicto al trabajo y con la cuota de poder que esto le daba, era en el fondo, como se percatase luego a raíz de su enfermedad, profundamente infeliz. Comenzó un buen día con un leve malestar en su flanco derecho, que progresivamente devino en un dolor intenso y que los médicos a los que consultara debatían si se alojaba en su riñón o en su ciego. Su condición se iba deteriorando rápidamente, pese a lo cual ni sus médicos, amigos ni familiares eran capaces de comunicarle abiertamente aquello que le estaba sucediendo. Finalmente termina comprendiendo por si solo su condición de paciente terminal. Dos cosas le causaban un dolor mas profundo que su enfermedad somática, la mentira y el abandono del que era objeto por parte de los suyos. Sin embargo, afortunadamente halló contención en su sirviente Guerasim quien lo atendió compasivamente hasta el final.

A lo largo de su padecer, Ivan llich transitó los senderos propios del enfermo terminal: consultas a la medicinas alopática y homeopática, e incluso a los métodos alternativos. Trataba en sueños de extirpar mágicamente la zona enferma en actos operatorios imaginarios que se esfumaban bruscamente ante los accesos de dolor, que lo regresaban a su cruda realidad. Por momentos repasaba en su mente los principales eventos de su vida, descubriendo con sorpresa los escasos islotes de felicidad que había experimentado y cómo había desperdiciado su preciada vida.Mantuvo la esperanza de subsistir hasta los últimos momentos y ante la más ínfima mejoría sintomática reanudaba sus ilusas expectativas de sanar, en un intento desesperado de aferrarse a la vida.Finalmente terminó por comprender que a esa altura de los acontecimientos su temor a morir era la razón principal de su padecer. Sólo después de ser capaz de aceptar la inminencia de su muerte y de entregarse a ella, finalizó su absurda agonía.
\end{abstract}

\section{Comentarios}

Si bien son varios los planos temáticos simultáneamente desarrollados en esta obra, la idea central de la misma es describir los laberintos del paciente terminal y su circunstancia. Otras ideas desarrolladas a lo largo del cuento son:

\section{La muerte siempre le parece al hombre un asunto ajeno:}

Todo hombre conoce la condición mortal de su especie, pero también es cierto que cree mágicamente que él será la excepción a esa regla. No fueron ajenos a esta falacia ni los amigos de Iván llich al enterarse de su muerte, ni el mismísimo Iván, quien atesoró todo el tiempo esta humana ilusión.

"El ejemplo del silogismo que había estudiado en la Lógica de Kizevérter: Cayo es un hombre, los hombres son mortales, luego Cayo es mortal, le pareció toda su vida correcto con relación a Cayo, pero no con relación a sí mismo".

La incapacidad de la medicina moderna para contener a este tipo de enfermos: La mala comunicación médicopaciente en la que se vio envuelto Iván llich facilitó la aparición en su alma de sentimientos de confusión y desolación. La mala actitud de su médico hacia él, con su soberbia, sus ocultamientos, la sistemática subestimación a sus preguntas, el uso de un lenguaje técnico en sus explicaciones y sobre todo la imposibilidad de contactarlo cuando lo necesitaba llevó a Iván a caer en la policonsulta, la desinformación y la incertidumbre.

"Para Iván había una sola pregunta importante: ¿Era o no era grave lo suyo? Ahora bien, el doctor no quería detenerse en una pregunta tan fuera de propósito..."

\section{La fragilidad de la condición humana}

La supuesta estabilidad laboral y social de la que gozaba Iván llich, el prestigioso juez de instrucción del Imperio Ruso, se desmoronó hasta la náusea con el decurso de su enfermedad.

"Inversamente proporcional al cuadrado de la distancia de la muerte, pensaba Iván llich. Y esa imagen de la piedra que cae cuesta abajo a creciente velocidad se le metía en el alma..."

\section{La compasión como refugio ante la desesperanza}

La compasión, que no es lo mismo que la lástima, es lo que en medicina conocemos como empatía o sentir a la par de otro su realidad. En el caso de Iván llich ésta le llegó de la mano de la persona más sencilla de su entorno, su siviente Guerasim precisamente por que fue el único que obró guiado por este sentimiento.

" -Todos hemos de morir. ¿Por qué no he de tomarme esta molestia?- dijo Guerasim, dando a entender que el trabajo no le significaba molestia alguna precisamente porque lo hacía para un moribundo y esperaba que, cuando a él le llegase la ocasión, habría otro que también lo haría".

\section{Los mecanismos defensivos humanos contra la deses-} peración

La negación del problema, la distracción de su pensamiento mediante temas menores (pantallas) y la ideación de soluciones mágicas circulan a lo largo de toda la obra.

"El riñón flotante, el riñón flotante. Recordó cuanto le dijeron los médicos de cómo se había desprendido y cómo flotaba. Con un esfuerzo de imaginación, trató de atrapar este riñón, de detenerlo y sujetarlo; le parecía que era muy poco lo que hacía falta hacer."

\section{La paradoja de la muerte}

La muerte es tautológica, pues sólo ella es inmortal. Al ser alcanzado por la muerte Iván llich se libera de ella, por eso dice hacia el final:

"¡Se acabó! - dijo alguien sobre él.

El oyó estas palabras y las repitió en su alma. Se acabó la muerte- se dijo- . La muerte no existe."

\section{Conclusión}

La lectura detallada de la obra La muerte de Iván Ilich del novelista León Tolstoi constituye un ejercicio excepcional para convivenciar y de esta forma realmente comprender los padecimientos atravesados por los pacientes terminales. 